\title{
Treatment of Kitchen Wastewater using Aerobic Biological Method and Sand-Bed Filtration
}

\author{
Ita E. Uwidia \\ Correspondence: Ita E. Uwidia, Department of Chemistry, University of Benin, Benin City, Nigeria. P.M.B. 1154, Benin \\ City, Nigeria.
}

Received: July 5, 2020 Accepted: August 31, 2020 Online Published: September 8, 2020

doi:10.5539/ijc.v12n2p12 URL: https://doi.org/10.5539/ijc.v12n2p12

\begin{abstract}
Increased global demand for freshwater far exceeds the quantity available for human sustenance. Wastewater recycling processes are necessary and capable of producing large volumes of water for reuse. In this study, raw kitchen wastewater was analyzed for physicochemical and microbiological characteristics before and after biological treatment and sand-bed filtration. The results revealed a reduction in the mean values of the following parameters: turbidity (from 6.9 to $6 \mathrm{NTU}$, a $13.04 \%$ reduction), conductivity (365 to $311 \mu \mathrm{S} / \mathrm{cm}$, a $14.79 \%$ reduction), total dissolved solids (141 to $121 \mathrm{mg} / \mathrm{L}$, a $14.18 \%$ reduction), total suspended solids ( 5 to $2 \mathrm{mg} / \mathrm{L}$, a $60 \%$ reduction), biochemical oxygen demand (5.5 to $1.82 \mathrm{mg} / \mathrm{L}$, a $66.9 \%$ reduction), chemical oxygen demand (36 to $32 \mathrm{mg} / \mathrm{L}$, an $11.11 \%$ reduction), and total bacterial count ( $286 \times 10^{-4}$ to $16 \times 10^{-4} \mathrm{CFU}$, a $94.41 \%$ reduction). The kitchen wastewater was suitable for non-potable reuse. Biological treatment and sand-bed filtration rendered the kitchen wastewater useful for secondary applications such as irrigation.
\end{abstract}

Keywords: Kitchen wastewater, aerobic biological treatment, sand-bed filtration, reuse

\section{Introduction}

Water is a vital natural resource and a primary human need. Large volumes of water are required daily for human activities such as food preparation, washing, toilet flushing, and other domestic and industrial activities. An abundant freshwater supply has been a long-standing problem, and only a small percentage of the world's population has access to safe, clean water. About 800 million people live under a threshold of water stress, and by estimation, this number may increase to 3 billion by 2025 (Michael et al., 2018). The global freshwater crisis has led to poor sanitation and depletion of our water resources, waterborne and water-related diseases, and increased death rates, particularly among children.

This crisis is the result of several factors such as improved standard of living, population growth, mismanagement and overuse of water resources, and climate change. Because water is a renewable resource, evaporation and precipitation in the environment ensures the freshwater supply. However, its global availability remains complex, low, and unevenly distributed. Over $97 \%$ of the earth's water is seawater, which is too salty for irrigation or domestic use. Water available in rivers and lakes are excellent sources of freshwater but contain only less than $0.01 \%$ of the world's freshwater resource for human use (Earkin and Sharman, 2010; Miroslav and Vladimir, 1999).

Kitchen wastewater can be defined as spent water from the kitchen sink without contamination from human urine or excrement. The quality of kitchen wastewater varies widely from one household to another daily depending on the activities of residents and products in the home. Wastewater from the kitchen is sometimes referred to as kitchen greywater or domestic wastewater (Al-Jayyousi, 2003).

Domestic wastewater can be separated into three forms such as black water (containing feces and urine), higher-load greywater, HLGW (i.e. wastewater from kitchen sink and washing machine), lower-load greywater LLGW (i.e. wastewater from shower bath and washbasin) (Huelgas, et al., 2009). Depending on the quality and composition kitchen wastewater can be of low pollution strength and may, therefore, contain easily biodegradable organic components and low pathogenic content. Therefore, such wastewaters will be much easier to treat, safer to recycle, and have a high potential for reuse (Bernard, et al., 2003; Michael, et al., 2018). Baths and showers generate the greatest volume of greywater but also contribute the greatest to microorganism load.

Kitchen wastewater may also contain significant nutrient load (particularly nitrogen and phosphorous) depending on the components in the water. Such wastewater will have the potential to cause algae blooms. Such nutrient-rich water will 
serve as a useful source of fertilizer for gardens and lawns. Treatment of kitchen wastewater includes secondary, tertiary, and biological treatment processes (Epperson, 1994; Christovba, et al., 1996; Al-Jayyousi, 2003). Wastewater reuse reduces the amount of wastewater entering the sewers or septic systems (Agunwamba, 2000). Wastewater recycling is useful because it will help to conserve water when there is a limited supply of clean water. (Eriksson, et al., 2003).

The research aimed to analyze the kitchen wastewater for pollution levels, treat the wastewater using sandbed filtration (as described by Asia and Akporhonor, (2007a)) to reduce as much as possible Total suspended solids, biochemical oxygen demand and other pollutants such that the water may be more environmentally friendly and feasible for non-portable reuse. The raw wastewater was obtained and analyzed for physicochemical and microbiological characteristics. Biological treatment was carried out on the wastewater followed by sand-bed filtration. The study showed that biological treatment and sand-bed filtration were effective and the treated kitchen wastewater was suitable for non-portable re-use.

\section{Materials and Methods}

\subsection{Sample Description and Collection}

The kitchen wastewater used for this study was from a fast-food restaurant in Benin-City, Edo State, Nigeria. Wastewater samples were obtained from the outlet pipe connected to the kitchen sink and conveying all spent water away from the kitchen into a receiver. The wastewater studied was strictly discharges from kitchen activities involving food preparations ranging from cutting of vegetables, meat, and fish preparations to dishwashing and other cooking activities.

Samples were collected at one-hour intervals for 5 hours using well-labeled two-liter plastic containers. The sample collection was done in the morning hours starting from 8.00 am and ending at noon. At the end of the sampling period, the various samples were mixed to form a composite sample. The $\mathrm{pH}$ was determined in situ. The composite sample was stored in an icebox and taken to the laboratory for further analysis. Where analysis was not immediately possible, the samples were refrigerated at $4^{\circ} \mathrm{C}$. The sand and gravel used for sand bed filtration were collected from a construction site at the University of Benin, Benin-City, Edo State, Nigeria.

\subsection{Method of Analysis}

Analyses were carried out using standard methods for analyzing water and wastewater.

The $\mathrm{pH}$, temperature, conductivity, turbidity and total dissolved solids were determined by electrometric methods using Hach water analysis kits (Model DR 2010). The Hach meter was calibrated using the reference standard from Hach by dipping the cell into the solution sample. Thereafter, $100 \mathrm{~mL}$ of the wastewater sample was placed in a $250 \mathrm{~mL}$ beaker and the probe was inserted. Readings that were displayed on the screen were taken after they had been allowed to stabilize. The determinations were carried out immediately after collecting the wastewater samples (APHA, 1995).

Total suspended solids and total alkalinity were determined by the gravimetric method according to standard methods using glass fiber filter paper (APHA, 1995). 100mL of the sample was filtered through a Whatman glass fiber filter disc ( $5.5 \mathrm{~cm}$ in diameter), using an air pump. Each filter was then placed on a tin tray (the tin trays and glass fiber filter were previously dried at $105^{\circ} \mathrm{C}$ and weighed in the oven) placed in the oven and dried at $105^{\circ} \mathrm{C}$ for two hours. The trays and used filters were weighed again. The difference between the final weight and initial weight gave the number of suspended solids in the sample. The total suspended solids was calculated as follows:

$$
\text { Total suspended solids }(\mathrm{mg} / \mathrm{L})=\frac{(\mathrm{A}-\mathrm{B}) \times 1000}{\text { Sample volume used }}
$$

Where $\mathrm{A}=$ Weight of glass fiber filter + dried residue in $\mathrm{mg}$

$\mathrm{B}=$ weight of filter paper in $\mathrm{mg}$

Sample volume used $=100 \mathrm{~mL}$.

Total alkalinity was determined by the titration method (APHA, 1995). Two drops of methyl orange indicator was added to $100 \mathrm{~mL}$ of the sample. The colored solution (yellow) was titrated against $0.02 \mathrm{~mL}$ standard $\mathrm{HCl}$ until the color changed from yellow to orange. Total alkalinity was calculated using the equation:

$$
\text { Total Alkalinity, } \mathrm{mg} \mathrm{CaC0}_{3} / \mathrm{L}=\frac{\text { BXN X } 5000}{\mathrm{~mL} \text { of sample }}
$$

Where:

$\mathrm{B}=$ total $\mathrm{mL}$ of titrant used to methyl orange endpoint 
$\mathrm{N}=$ Normality of titrant $(0.02 \mathrm{M})$

Total hardness was determined by EDTA titrimetric method (APHA, 1995). $5 \mathrm{~mL}$ of the sample was diluted to $10 \mathrm{~mL}$ with distilled water and $1 \mathrm{~mL}$ of the buffer was added to give a $\mathrm{pH} 10.0$.

Two drops of indicator solution were added and titrated with EDTA titrant $(0.01 \mathrm{M})$ to a blue point. The EDTA titrant was standardized against the standard calcium solution. Total hardness was calculated as follows:

$$
\text { Total Hardness (EDTA), } \mathrm{mg} \mathrm{CaCO}_{3} / \mathrm{L}=\frac{\mathrm{A} \times \mathrm{B} \times 1000}{\mathrm{~mL} \text { sample }}
$$

Where:

$\mathrm{A}=\mathrm{mL}$ EDTA titrated for sample

$\mathrm{B}=\mathrm{mg} \mathrm{CaCO}_{3}$ equivalent to $1.00 \mathrm{~mL}$ EDTA sample.

Dissolved oxygen (DO) was determined using the Azide modification of Winkler's method (APHA, 1995; Ademoroti, 1996a). Wastewater samples were collected in $250 \mathrm{~mL}$ DO bottles. Immediately after collection $2 \mathrm{~mL}$ each of Winkler solution was added to each bottle followed by sodium azide dissolved in $4 \mathrm{~mL}$ of distilled water to fix the oxygen. The bottles were covered and contents thoroughly mixed by inverting the bottles several times. The samples were then taken to the laboratory. Two $\mathrm{mL}$ of concentrated $\mathrm{H}_{2} \mathrm{SO}_{4}$ was added to dissolve the precipitate. Finally, $203 \mathrm{~mL}$ of the sample was titrated from each DO bottle against $0.0125 \mathrm{M}$ sodium thiosulphate solution to a colorless endpoint. Dissolved oxygen was calculated as:

$$
\mathrm{DO}(\mathrm{mg} / \mathrm{L})=\frac{16000 \times \mathrm{M} \times \mathrm{V}}{\mathrm{V} 1-2.0}
$$

Biochemical oxygen demand (BOD) was determined using the iodometric method. Initial dissolved oxygen was determined in the first set of samples according to the method described for dissolved oxygen above. The second set of samples were diluted with dilution water and incubated in the dark for 5 days at $20^{\circ} \mathrm{C}$ followed by final DO determination. Finally, BOD was determined using the following calculation:

$$
\mathrm{BOD}(\mathrm{mg} / \mathrm{L})=\frac{\mathrm{IDO}-\mathrm{DO} 5}{\mathrm{P}}
$$

Where:

IDO = Initial dissolved oxygen in the sample

$\mathrm{DO}_{5}=$ Dissolved oxygen in the sample after five days of incubation

$\mathrm{P}=$ Percent dilution.

Chemical oxygen demand (COD) was determined by the closed reflux titrimetric method (APHA, 1995). The wastewater sample $(50 \mathrm{~mL}), 1 \mathrm{~g}$ of $\mathrm{HgSO}_{4}$, some glass beads, and $5.0 \mathrm{~mL}$ sulphuric acid (added very slowly) were well mixed in a $500 \mathrm{~mL}$ round-bottomed flask and allowed to cool. $25 \mathrm{~mL}$ of $0.0417 \mathrm{M}$ potassium dichromate digestion solution was added and mixed. While cooling, $70 \mathrm{~mL}$ of the remaining sulphuric acid reagent was added (with the aid of a condenser attached to the flask) with continuous swirling. The open end of the condenser was covered with glass wool and the mixture was refluxed for 2 hours. After digestion, the mixture was diluted to twice its volume with distilled water and the excess dichromate was titrated against $0.25 \mathrm{M}$ ferrous ammonium sulfate titrant (FAS) using $0.10 \mathrm{~mL}$ of ferroin indicator. The endpoint was a sharp color change from blue-green to reddish-brown. Blank determinations were also carried out. The COD was calculated as follows:

$$
\operatorname{COD}(\mathrm{mg} / \mathrm{L})=\frac{(\mathrm{A}-\mathrm{B}) \times \mathrm{M} \times 8000}{\mathrm{~mL} \text { of sample }}
$$

Where:

$\mathrm{A}=\mathrm{mL}$ of FAS used

$\mathrm{B}=\mathrm{mL}$ of FAS used for sample

$\mathrm{M}=$ Molarity of FAS

Percentage reduction was calculated to determine compositional changes between the raw and treated wastewater using the following: 


$$
\frac{\mathrm{A}-\mathrm{B}}{\mathrm{A}} \times 100
$$

Where:

$\mathrm{A}=$ Value for the raw parameter

$\mathrm{B}=$ Value for the treated parameter

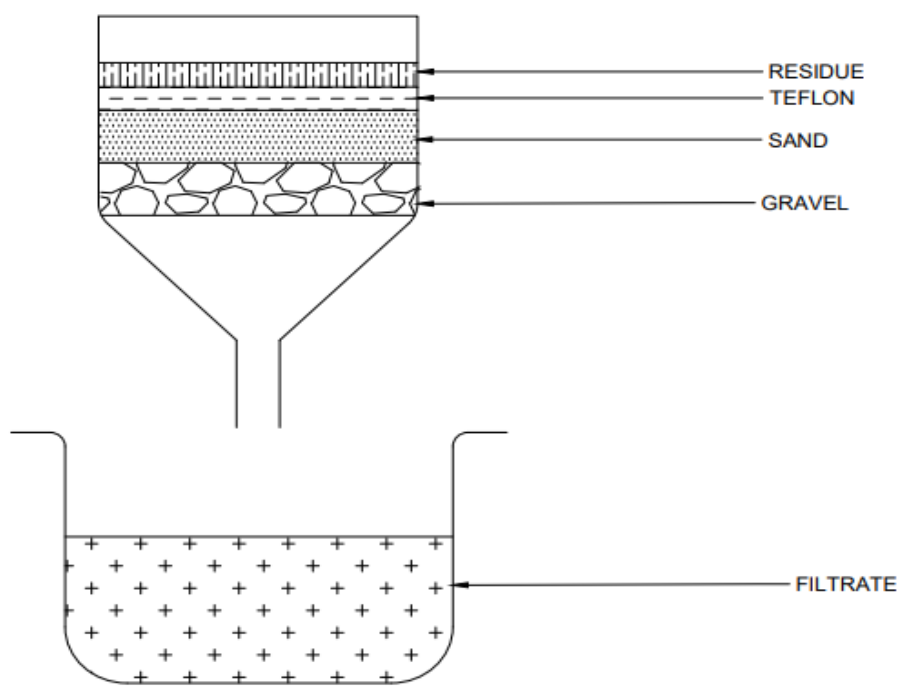

Figure 1. Configuration of the Sand-Bed Filtration

\subsubsection{Biological Treatment}

Biological treatment was carried out on a bench-scale as described by Asia and Ademoroti, 2004 with slight modifications.

Clay pots of 2 to 3-liter capacity were filled with the raw kitchen wastewater. $5 \mathrm{~mL}$ phosphate solution was added as a buffer. $1 \mathrm{~mL}$ each of magnesium sulfate, calcium chloride, iron (III) chloride solutions were added to give adequate nutrients to the bacteria population in the wastewater (Asia and Ademoroti, 2004; Metcalf and Eddy, 2003). Clay pots were improvised as used earthen vessels in place of a wastewater treatment lagoon. Mechanical aeration was carried out at 3-hour intervals daily and the $\mathrm{pH}$ was monitored until a stable $\mathrm{pH}$ was obtained.

\subsubsection{Sand-bed Filtration}

After biological treatment, the resulting wastewater was filtered using a sand bed filtration medium. The column of sand was packed with Teflon material followed by sand and gravel in different layers. The layers of sand (fine sand and coarse

sand) were each $20 \mathrm{~cm}$ in height and gravel was $10 \mathrm{~cm}$ in height. The sand and gravel were previously washed thoroughly with a solution of $0.1 \mathrm{M}$ nitric acid to remove impurities that may be present and allowed to dry. The filtered sample was finally analyzed for physicochemical and microbiological characteristics.

\section{Results and Discussion}

Results of the analysis for raw and treated samples of the kitchen greywater are as shown in Table 1.

Also, Table 2 shows a comparison of raw and treated values. 
Table 1. Summary of Results Obtained from the Analyses

\begin{tabular}{lccc}
\hline \multirow{2}{*}{ Parameters } & Unit & Raw Kitchen Wastewater & Treated Kitchen Wastewater \\
\cline { 3 - 4 } & & Mean \pm SD & Mean \pm SD \\
\hline \multicolumn{1}{c}{$\mathrm{pH}$} & & $7.4 \pm 0.057$ & $7.9 \pm 0.000$ \\
\hline Temperature & ${ }^{\circ} \mathrm{C}$ & $29 \pm 0.060$ & $31 \pm 1.700$ \\
\hline Turbidity & $\mathrm{NTU}$ & $6.9 \pm 0.127$ & $6.0 \pm 0.2333$ \\
\hline Conductivity & $\mu \mathrm{S} / \mathrm{cm}$ & $365 \pm 0.000$ & $311 \pm 10.270$ \\
\hline Total Dissolved Solids (TDS) & $\mathrm{mg} / \mathrm{L}$ & $141 \pm 8.505$ & $121 \pm 2.944$ \\
\hline Total Suspended Solids (TSS) & $\mathrm{mg} / \mathrm{L}$ & $5.0 \pm 3.536$ & $2.0 \pm 0.000$ \\
\hline Alkalinity & $\mathrm{mg} / \mathrm{L}$ & $6.3 \pm 0.000$ & $7.3 \pm 0.000$ \\
\hline Biochemical oxygen demand (BOD) & $\mathrm{mg} / \mathrm{L}$ & $5.5 \pm 0.000$ & $1.82 \pm 0.000$ \\
\hline Chemical oxygen demand (COD) & $\mathrm{mg} / \mathrm{L}$ & $36.0 \pm 0.000$ & $32.0 \pm 0.000$ \\
\hline Total Bacterial count (E.coli) & $\mathrm{CFU}$ & $286 \times 10^{-4}$ & $16 \times 10^{-4}$ \\
\hline
\end{tabular}

Table 2. Comparative Analysis of Compositional Changes in the Raw and Treated Kitchen Wastewater

\begin{tabular}{lcccc}
\hline Parameters & Units & $\begin{array}{l}\text { Raw Kitchen } \\
\text { Wastewater }\end{array}$ & $\begin{array}{c}\text { Treated } \\
\text { Kitchen } \\
\text { Wastewater }\end{array}$ & $\begin{array}{c}\text { Percentage } \\
\text { Treatment }(\%)\end{array}$ \\
\hline Turbidity & & Mean \pm SD & Mean \pm SD & \\
\hline Conductivity & NTU & $6.9 \pm 0.127$ & $6.0 \pm 0.23$ & $13.04 \downarrow$ \\
\hline Total dissolved solids (TDS) & $\mathrm{mg} / \mathrm{L}$ & $141 \pm 8.505$ & $121 \pm 2.94$ & $14.79 \downarrow$ \\
\hline Total Suspended Solids (TSS) & $\mathrm{mg} / \mathrm{L}$ & $5.0 \pm 3.536$ & $2.0 \pm 0.00$ & $14.18 \downarrow$ \\
\hline $\begin{array}{l}\text { Biochemical oxygen demand } \\
\text { (BOD) }\end{array}$ & $\mathrm{mg} / \mathrm{L}$ & $5.5 \pm 0.000$ & $1.82 \pm 0.00$ & $66.90 \downarrow$ \\
\hline $\begin{array}{l}\text { Chemical oxygen demand } \\
\text { (COD) }\end{array}$ & $\mathrm{mg} / \mathrm{L}$ & $36.0 \pm 0.000$ & $32.0 \pm 0.00$ & $11.11 \downarrow$ \\
\hline Total Bacteria count (E.coli) & $\mathrm{CFU}$ & $286 \times 10^{-4}$ & $16 \times 10^{-4}$ & \\
\hline
\end{tabular}

$\mathrm{SD}=$ Standard deviation

$\mathrm{NA}=$ Not available; $\mathrm{CFU}=$ colony forming unit.

Compositional changes in the raw and treated samples in terms of percentage reduction are presented in Table 2 . The conductivity of the raw sample was $365 \mu \mathrm{S} / \mathrm{cm}$ compared with $311 \mu \mathrm{S} / \mathrm{cm}$ in the treated samples. Comparing the raw result with the treated, the percentage reduction in conductivity after treatment was $14.79 \%$. Since electric conductivity measures the ability of a sample of water to convey electric current, results show that the dissolved ions responsible for conveying current in the wastewater have been slightly reduced. The slight reduction in conductivity may be due to the reduction of nutrients such as nitrates or phosphates in the wastewater during the biological process. Studies have shown that the conductivity of wastewater can be reduced by biological nutrient removal which can be explained by the algal-bacteria symbiosis. Ions responsible for conductivity are hydrogen ions, hydroxide ions, and nutrients such as nitrates and phosphates resulting from organic substances in the wastewater (Levlin, 2007; Mulu and Ayenew, 2015; Metcalf and Eddy, 2003). Aerobic heterotrophic bacteria present in the wastewater degrade the organic matter to carbon dioxide (or bicarbonate) and algal cells. These new cells use nutrients for photosynthesis and therefore the initial nutrient concentration is reduced. Similarly, the reduction in conductivity was reflected in the result for total dissolved solids which reduced from $141 \mathrm{mg} / \mathrm{L}$ (raw sample) to $121 \mathrm{mg} / \mathrm{L}$ (treated sample) with a percentage reduction of $14.18 \%$. The result obtained for conductivity and total dissolved solids is in agreement with studies on the effect of sand-bed filtration carried out by Akporhonor and Asia (2007b) and Metcalf and Eddy (2003) which showed that filtration had an only marginal effect on TDS and conductivity. Also, ions responsible for conductivity were not affected by the sand-bed filtration. Therefore the slight reduction observed for total dissolved solids and conductivity in this study must have 
resulted from a reduction of the dissolved ionic matter responsible for conductivity in the wastewater samples during the biological treatment. Substances dissolved in the wastewater may be due to organic proteins, carbohydrates, mineral salts, esters, oils, or other organic solutes (Uwidia and Ademoroti, 2011).

Total suspended solids values were $5.0 \mathrm{mg} / \mathrm{L}$ (raw sample) and $2.0 \mathrm{mg} / \mathrm{L}$ (treated sample) with a percentage reduction of $60 \%$. The decrease in the total suspended solids showed that the mechanism of filtration (following aerobic biodegradation) using sand- bed and Teflon material helped to remove large amounts of flocs and other suspended solids. Microorganisms decompose organic matter in wastewater through biological oxidation and biosynthesis. From the aerobic biological treatment, dissolved minerals and other substances remain in the solution. However, biosynthesis transforms colloidal and dissolved organic matter into new cells which in turn form dense biomass and can be removed by filtration (Samer, 2015; Ademoroti, 1996b; Mulu and Ayenew, 2015) as shown in the equation below.

Oxidation:

$$
\text { (Organic compounds) } \mathrm{COHNS}+\mathrm{O}_{2}+\text { Bacteria } \longrightarrow \mathrm{CO}_{2}+\mathrm{NH}_{3}\left(\text { or } \mathrm{NO}^{-}\right)+\mathrm{S}\left(\text { or } \mathrm{SO}_{2}\right)
$$

Biosynthesis:

$$
\mathrm{COHNS}+\mathrm{O}_{2}+\text { Bacteria } \longrightarrow \mathrm{C}_{5} \mathrm{H}_{7} \mathrm{NO}_{2} \text { (New cells) }
$$

There was a decrease in BOD value from $5.5 \mathrm{mg} / \mathrm{L}$ (raw sample) to $1.82 \mathrm{mg} / \mathrm{L}$ (treated sample) and the percentage reduction was $66.9 \%$. This showed that the aerobic biological treatment process significantly reduced biodegradable organic materials present in the kitchen wastewater.

Chemical oxygen demand values were lower in the treated effluent $(32 \mathrm{mg} / \mathrm{L})$ compared with the raw effluent $(36 \mathrm{mg} / \mathrm{L})$. The percentage reduction achieved after treatment was $11.11 \%$. This showed that there was also slight chemical oxidation of some organic and inorganic substances in the wastewater by dichromate action. However, alkalinity increased from $6.3 \mathrm{mg} / \mathrm{L}$ (raw sample) to $7.3 \mathrm{mg} / \mathrm{L}$ in the treated sample. This was reflected in a slight increase in the $\mathrm{pH}$ values (from 7.4 to 7.9). The slight increase in $\mathrm{pH}$ indicates a tilt towards basicity. An increase in $\mathrm{pH}$ can be caused by algal photosynthesis in wastewater systems (Mulu and Ayenew, 2015). High alkalinity in the water may be a reflection of the decomposition of protein and some nitrogenous compounds in the water. However, no health implication has been identified with alkalinity (Gupta and Gupta, 2006). Total bacteria count was also reduced after treatment from 286 $\times 10^{-4}$ to $16 \times 10^{-4}$. The percentage reduction was $94.41 \%$ which indicated reduced levels of microbial contamination. Similar studies on the aerobic treatment of kitchen wastewater for recycling using activated sludge revealed the following percentage reductions in the parameters analyzed: BOD $(85 \%), \operatorname{COD}(87 \%)$, Conductivity (20.82), $\operatorname{TDS}(20.81 \%)$, TSS(85.21\%), Turbidity(72.61\%) (Habib, 2011) showing the effectiveness of different biological treatment processes using aerobic methods.

\subsection{Industrial Significance}

The aerobic biological method and sand-bed filtration used was cost-effective. The clay pots used in the biological treatment and other materials used in filtration were locally sourced. The method is renewable and the activity can be regenerated with little or no secondary hazard. Also, the process involves simple operational and maintenance requirements compared with other biological treatment systems.

\section{Conclusion}

The process of reducing pollution levels of kitchen wastewater using aerobic biological treatment and sand-bed filtration has been studied. Evidence from the study indicated that the treatment process achieved a significant reduction in some parameters such as a $60 \%$ reduction in total suspended solids, $66.90 \%$ reduction in biochemical oxygen demand, and $94.1 \%$ reduction in total bacteria count. Other parameters slightly reduced were chemical oxygen demand (11.11\%), turbidity $(13.04 \%)$, and total dissolved solids $(14.18 \%)$ conductivity $(14.79 \%)$. The result showed that biodegradation and sand-bed filtration was effective for reducing solids, organic, and some inorganic contents in kitchen wastewater. The treated wastewater could serve for secondary or non-portable reuse such as irrigation, and other outdoor uses.

\section{References}

Ademoroti, C. M. A. (1996a). Standard methods for water and effluents analysis. Ibadan, Nigeria: Foludex Press Limited.

Ademoroti, C. M. A. (1996b). Environmental chemistry and toxicology. Ibadan, Nigeria: Foludex Press Limited.

Agunwamba, J. C. (2000). Water engineering system. Nigeria: Immaculate Publications Limited.

Akporhonor, E. E., \& Asia, I. O. (2007a). The effect of sand-bed filtration on the oxygen demand characteristics of wastewaters from domestic, institutional and industrial sources. African Journal of Biotechnology, 6(18), 2119-2121. https://doi.org/10.5897/AJB2007.000-2329 
Akporhonor, E. E., \& Asia, I. O. (2007b). Characterization and physicochemical treatment of wastewater from rubber processing factory. International Journal of Physical Sciences, 2(3), 061-067.

Al-Jayyousi, O. R. (2003). Greywater reuse toward sustainable water management. India: Boa publications Limited. https://doi.org/10.1016/S0011-9164(03)00340-0

APHA, American Public Health Association. (1995). Standard methods for the examination of water and wastewater (20th ed.). Washington, DC: American Public Health Association.

Asia, I. O., \& Ademoroti, C. M. A. (2004). Integrated biological and chemical treatment of brewery sludge. Pakistan Journal of Science and Industrial Research, 47(4), 281-291.

Bernard, N., Lewin, D., \& Pitcher, D. O. (2003). Active carbons prepared by chemical activation of plum stones and their applications. Journal of Hazardous Materials, 181(2), 1088-1094. https://doi.org/10.1016/j.jhazmat.2010.05.126

Christovba, B., Eden, W., \& Farlane, S. (1996). Desalination of sea water. Belgium: Hackman Enterprises.

Earkin, B. W., \& Sharman, G. F. (2010). Volumes of the world's oceans from ETOPO1, NOAA, National Geophysical Data center. Retrieved from https://www.ngdc.noaa.gov/mgg/global/etopo1__ocean_volumes.html.

Epperson, P. (1994). Preparation and characteristics of rice straw based porous carbons with high adsorption capacity. Journal of Health Engineering, 81(3), 327-336. https://doi.org/10.1016/S0016-2361(01)00171-5

Eriksson, A., Eilersen, K., Henze, A. M., \& Ledin, M. (2003). Household chemicals and personal care product as sources for xenobiotic organic compounds in grey wastewater. Journal of Environmental Research and Technology, 29(2), 135-146. https://doi.org/10.4314/wsa.v29i2.4848

Gupta, S. K., \& Gupta, P. C. (2006). General and applied technology (Fish and Fisheries). New Delhi: S. Chand and Company.

Habib, U. (2011). Aerobic treatment for recycling kitchen wastewater. International Journal of Agriculture and Applied Sciences, 3, 1-8.

Huelgas, A., Nakajima, M., Nagata, H., \& Funamizu, N. (2009). Comparison between treatment of kitchen - sink wastewater and a mixture kitchen - sink and washing machine wastewater. Environmental technology, 30(1), 111-117. https://doi.org/10.1080/09593330802445549

Levlin, E. (2007). Conductivity Measurements for Controlling Municipal Waste-Water Treatment. Retrieved August 23, 2020 from KTH Royal Institute of Technology. https://www.kth.se/polopoly_fs/1.648828.1550154719!/JPSU15p51.pdf

Metcalf \& Eddy (2003). Wastewater Engineering: Collection, Treatment, and Disposal. New York N.Y: McGraw-Hill, Inc.

Michael, O., Mike, A. A., \& Nanne, K. (2018). Greywater characteristics, treatment systems, reuse strategies and user perception - a review. Water Air Soil Pollution, 229(225), 2-15. https://doi.org/10.1007/s11270-018-3909-8

Miroslav, R., \& Vladimir, B. N. (1999). Practical environmental analysis. The Royal Society Chemistry Cambridge, UK., 138-146.

Mulu, A., \& Ayenew, T. (2015) Characterization of abattoir wastewater and evaluation of the effectiveness of the wastewater treatment systems in Luna and Kera Abattoirs in Central Ethiopia. International Journal of Science and Engineering Research, 6(4), 1026-1040.

Samer, M. (2015). Biological and chemical wastewater treatment processes. https://doi.org/10.5772/61250

\section{Copyrights}

Copyright for this article is retained by the author(s), with first publication rights granted to the journal.

This is an open-access article distributed under the terms and conditions of the Creative Commons Attribution license (http://creativecommons.org/licenses/by/4.0/). 